\title{
Petrogenesis of a late-Variscan rhyodacite at the Ossa Morena-Central Iberian zones boundary, Iberian Massif, Central Portugal: Evidence for the involvement of lithospheric mantle and meta-igneous lower crust
}

\author{
S.B.A. Henriques ${ }^{\mathrm{a}, *}$, A.M.R. Neiva ${ }^{\mathrm{b}}$, G.R. Dunning ${ }^{\mathrm{c}}$ \\ ${ }^{a}$ Geobiotec, LNEG: Geology, Hydrogeology and Coastal Geology Department, Estrada da Portela, Bairro do Zambujal, Ap. 7586-Alfragide, 2610-999 \\ Amadora, Portugal \\ ${ }^{\mathrm{b}}$ Geobiotec, Department of Earth Sciences, University of Coimbra, 3030-790 Coimbra, Portugal \\ ${ }^{\text {c }}$ Earth Sciences Department, Memorial University, St. John's, NL A1B 3X5, Canada
}

\section{A R T I C L E I N F O}

\section{Article history:}

Received 18 February 2016

Received in revised form 8 June 2016

Accepted 11 June 2016

Editorial handling - A. Holzheid

\section{Keywords:}

Carboniferous

Igneous monazite

Inherited zircon

ID-TIMS U-Pb geochronology

$\mathrm{Sr}, \mathrm{Sm}-\mathrm{Nd}$ and $\delta^{18} \mathrm{O}$ isotopes

\begin{abstract}
A B S T R A C T
A late-Variscan rhyodacite is exposed at the contact between the Ossa Morena Zone and the Central Iberian Zone of the Iberian Massif, Central Portugal. Dykes of rhyodacite intruded the Série Negra Unit and the Sardoal Complex that are part of the Cadomian basement. The igneous crystallization age of the rhyodacite ( $308 \pm 1 \mathrm{Ma}$ ) was obtained on igneous monazite by the ID-TIMS U-Pb method. It is broadly coeval with the emplacement of late-Variscan granitoids during the last deformation phase of the Variscan Orogeny (ca. 304-314 Ma) and with the development of the large late-Variscan strike-slip shear zones (ca. $307 \mathrm{Ma}$ ). The rhyodacite samples are calc-alkaline, show identical composition and belong to the same magmatic sequence. The rhyodacite isotopic signatures $\left(\mathrm{Sm}-\mathrm{Nd}\right.$ and $\left.\delta^{18} \mathrm{O}\right)$ are consistent with depleted-mantle juvenile sources and the contribution of the meta-igneous lower crust. The input of mantle juvenile sources is related to Variscan reactivation of lithospheric fractures. The inherited Neoproterozoic (ca. 619 Ma) and Mesoproterozoic (ca. $1054 \mathrm{Ma}$ ) zircon ages, are similar to those of the Central Iberian Zone. This suggests that lower crust of the Central Iberian Zone was involved in the magma generation of the rhyodacite. Coeval late-Variscan magmatic rocks display a larger contribution from ancient crustal components, which may be attributed to the smaller volume and faster cooling rate of the rhyodacite and consequent lower melting of the crust. Mixing of juvenile mantle-derived melts with melts from the lower continental crust was followed by fractional crystallization of garnet and amphibole that remained in the source. Fractional crystallization of plagioclase, biotite, quartz and zircon occurred in shallower magma chambers. Fractional crystallization of zircon was not significant.
\end{abstract}

(c) 2016 Elsevier GmbH. All rights reserved.

\section{Introduction}

The closure of the Rheic Ocean occurred in the DevonianCarboniferous due to the continental collision between Laurussia, the peri-Gondwanan terranes and Gondwana that gave rise in Europe to the Variscan orogeny (e.g. Gutiérrez-Alonso et al., 2004; Matte, 2001; Murphy et al., 2014 and references therein). During the post collisional stage of the Variscan orogeny large volumes of granitoids were emplaced in the Central Iberian Zone and at the contact with the Ossa Morena Zone (e.g. Carracedo et al., 2009; Dias

\footnotetext{
* Corresponding author.

E-mail addresses:

sbahgeo@gmail.com, susana.henriques@lneg.pt (S.B.A. Henriques), neiva@dct.uc.pt (A.M.R. Neiva), gdunning@mun.ca (G.R. Dunning).
}

et al., 2002; Ferreira et al., 1987). The late-Variscan granitoids (ca. 306-311 Ma; e.g. Dias et al., 2002) correspond to abundant S-type granites (e.g. Teixeira et al., 2011), rare I-type granites (e.g. Villaseca et al., 2009) and hybrid granites (e.g. Gomes and Neiva, 2005).

At the contact between the Ossa Morena Zone and the Central Iberian Zone, a late-Variscan rhyodacite crops out, near Abrantes, Central Portugal. This contact is a key locality for the understanding of the late-Variscan magmatism, because it represents an important Neoproterozoic suture reactivated during the Variscan orogeny (e.g. Eguíluz et al., 2000; Henriques et al., 2015; Ribeiro et al., 2009). In this paper we present the first study of the rhyodacite, which includes the description of field relationships, petrography, mineral chemistry, U-Pb geochronology, whole rock geochemistry and isotopic data $\left(\mathrm{Sr}, \mathrm{Sm}-\mathrm{Nd}, \delta^{18} \mathrm{O}\right)$. The aim of this study is to characterize the magmatic sources of the rhyodacite as well as the main magmatic processes involved in its petrogenesis. 